\title{
PEMBELAJARAN KOOPERATIF INVESTIGATIF UNTUK MENINGKATKAN PEMAHAMAN SISWA MATERI BARISAN DAN DERET
}

\author{
Masjudin \\ Program Studi Pendidikan Matematika, FPMIPA, IKIP Mataram \\ Email: masjudinmath@yahoo.co.id
}

\begin{abstract}
Abstrak
Berdasarkan hasil observasi awal di SMAN 1 Batu, ditemukan permasalahan dalam pembelajaran matematika di kelas XII IPA 3. Permasalahan tersebut adalah: (a) Siswa tidak terlibat secara aktif dalam proses belajar mengajar; (b) Sebagian besar siswa belajar matematika hanya dengan menghafal rumus; dan (c) guru mendominasi dalam pembelajaran. Akibatnya, siswa tidak dapat memahami materi pelajaran dengan baik sehingga hasil belajar matematika siswa menjadi rendah. Penelitian ini bertujuan untuk meningkatkan pemahaman siswa materi barisan dan deret melalui pembelajaran kooperatif investigatif di kelas XII IPA 3 SMAN 1 Batu. Jenis penelitian ini adalah penelitian tindakan kelas (PTK). Instrumen pengumpulan data meliputi Lembar evaluasi, lembar observasi aktivitas guru dan siswa, format wawancara, catatan lapangan, dan dokumentasi yang meliputi Lembar Kerja Siswa (LKS) dan dokumentasi pembelajaran di kelas (photo). Kriteria keberhasilan yang ditetapkan pada penelitian ini adalah siswa mendapatkan nilai lebih dari atau sama dengan 75. Data hasil tes akhir menunjukkan bahwa nilai terendah yang diperoleh siswa adalah 77. Dengan demikian, kiteria keberhasilan yang ditetapkan untuk hasil tes akhir telah tercapai. Oleh karena itu, dapat disimpulkan bahwa melalui pembelajaran kooperatif investigatif dapat meningkatkan pemahaman siswa pada materi barisan dan deret.
\end{abstract}

Kata Kunci: Pembelajaran Kooperatif Investigatif; Pemahaman; Barisan dan Deret

\section{PENDAHULUAN}

Matematika dikenal sebagai suatu ilmu pengetahuan yang abstrak, yang dapat dipandang sebagai menstrukturkan pola, berpikir sistematis, kritis, logis, dan konsisten. Karena keabstrakannya tersebut matematika seringkali menjadi matapelajaran yang sulit dirasakan sebagian siswa. Padahal matematika juga dapat diartikan sebagai aktivitas manusia. Artinya, matematika tidak dapat dipisahkan dengan kehidupan manusia. Setiap kegiatan manusia akan membutuhkan yang namanya matematika. Oleh karena itu, matematika sebagai aktivitas manusia berarti manusia harus diberi kesempatan untuk menemukan kembali ide dan konsep matematika dengan bimbingan orang dewasa secara terstruktur, sistematis, kritis, logis, dan konsisten.

Pada pembelajaran matematika secara umum, sistem pembelajaran yang digunakan selama ini lebih diinspirasi oleh pandangan yang memandang bahwa matematika merupakan suatu produk yang siap saji. Siswa dibelajarkan dengan konsep-konsep atau prosedur-prosedur baku. Pembelajaran hanya didasarkan pada buku paket yang dipenuhi dengan simbol-simbol dan rumus-rumus. Kemudian simbol-simbol dan rumus-rumus tersebut harus dihafalkan oleh siswa tanpa pemahaman.

Jika jika pandangan seperti ini dilaksanakan dalam pembelajaran, maka tentu akan sangat berbahaya bagi pemahaman matematika siswa. padahal dalam pembelajaran matematika, yang paling dibutuhkan adalah pemahaman, bukan hafalan. Hal tersebut sesuai dengan pendapat Hiebert \& Carpenter, (1992) yang menyatakan bahwa pemahaman merupakan aspek penting dalam belajar matematika. Selanjutnya, Hudojo (1998) juga menyatakan: "inti pembelajaran matematika adalah pemahaman bukan pemerolehan". Katona (dalam Orton, 1992) menyatakan: "siswa yang belajar melalui pemahaman akan lebih sukses dari pada belajar dengan hafalan". 


\section{JEMS (Jurnal Edukasi Matematika dan Sains)}

Tersedia online di: http://e-journal.ikippgrimadiun.ac.id/index.php/JEMS

Volume 4, Nomor 2, September 2016, hal 76-84

Berdasarkan hasil observasi awal proses pembelajaran di kelas XII IPA SMAN I Batu, diperoleh informasi bahwa dalam pembelajaran matematika, guru biasanya menyajikan materi kepada siswa dengan cara yang monoton, yaitu menyajikan materi, memberi contoh soal, dan memberikan soal latihan. Selain itu, guru lebih banyak mendominasi kegiatan pembelajaran. Situasi pembelajaran yang semacam ini menyebabkan siswa hanya menjadi pendengar. Bahkan, siswa cenderung mengantuk dalam menerima informasi atau materi yang disampaikan. Dengan metode pembelajaran seperti ini, guru tidak memberikan kesempatan siswa untuk mengkonstruksi pengetahuan matematikanya sendiri. Hal ini akan membuat siswa menjadi pasif sehingga pembelajaran matematika terkesan membosankan dan bahkan menakutkan. Akhirnya, banyak siswa tumbuh tanpa menyukai matematika sama sekali.
Berdasarkan dialog yang dilakukan dengan guru bidang studi matematika kelas XII IPA 2, diperoleh dua permasalahan dalam pembelajaran matematika, termasuk dalam pembelajaran tentang barisan dan deret. Pertama, keaktifan siswa dalam proses belajar mengajar rendah. Kedua, siswa belajar matematika seringkali hanya dengan menghafal rumus-rumus yang telah diperolehnya sehingga mereka sulit dalam menyelesaikan masalah, terutama masalahmasalah aplikatif.

Permasalahan-permasalahan di atas mengakibatkan siswa menjadi kurang memahami materi yang dipelajari dan pada akhirnya bermuara pada rendahnya prestasi belajar matematika siswa. Rendahnya prestasi belajar matematika siswa pada materi barisan dan deret di kelas XII IPA SMAN 1 Batu tahun pelajaran 2009/2010 dapat dilihat pada Tabel

Tabel 1 Daftar Nilai Ujian Blok Materi Barisan dan Deret Siswa Kelas XII IPA Semester Genap Tahun Ajaran 2009/2010

\begin{tabular}{llrl}
\hline No & Kelas & Rata-rata & Ketuntasan Belajar \\
\hline 1 & XII IPA 1 & 73,9 & $76,2 \%$ \\
\hline 2 & XII IPA 2 & 72,8 & $70,8 \%$ \\
\hline 3 & XII IPA 3 & 68,5 & $70,7 \%$ \\
\hline 4 & XII IPA 4 & 69,2 & $71,9 \%$ \\
\hline
\end{tabular}

Tabel 1 merupakan tabel yang menyajikan data nilai ujian blok materi barisan dan deret siswa pada tahun pelajaran 2009/2010. Dari Tabel 1 tersebut diperoleh informasi bahwa hasil belajar yang diperoleh siswa di semua kelas masih belum memenuhi kriteria ketuntasan klasikal (KK) yang telah ditetapkan sekolah. Klasikal (KK) yang ditetapkan sekolah $85 \%$ siswa mendapatkan nilai lebih dari atau sama dengan 75 .

Penelitian tentang materi barisan dan deret pernah dilakukan beberapa peneliti. Hasil penelitian tersebut menunjukkan bahwa dalam pembelajaran materi barisan dan deret terdapat beberapa masalah. Menurut Pandjo (2003), "selama ini pembelajaran barisan dan deret cenderung menekankan pada hafalan rumus suku ke-n (Un) atau rumus jumlah n-suku pertama (Sn)". Hasil temuan tersebut sejalan dengan hasil temuan penelitian yang dilakukan oleh As'ari. Dalam laporan hasil penelitiannya, As'ari (2002) menyatakan bahwa "rumus- rumus umum cenderung diberikan terlebih dahulu tanpa memahami dari mana asalnya". Belajar dengan cara menghafal seperti ini akan mengakibatkan siswa tidak dapat memahami konsep barisan dan deret dengan baik dan akan menjadikan siswa cepat lupa.

Data rendahnya hasil belajar siswa dan adanya permasalahan dalam pembelajaran materi barisan dan deret tersebut menunjukkan bahwa materi barisan dan deret belum dapat dipahami dengan baik dan belum bermakna bagi siswa. Oleh karena itu, dalam pembelajaran barisan dan deret diperlukan suatu strategi yang tepat sehingga konsep materi ini dapat dipahami dengan baik dan bermakna bagi siswa. Strategi yang memberikan kesempatan kepada siswa untuk terlibat aktif dalam pembelajaran.

Salah satu strategi pembelajaran yang desainnya banyak melibatkan siswa dalam proses pembelajaran adalah pembelajaran kooperatif investigatif. "Dalam pembelajaran 


\section{JEMS (Jurnal Edukasi Matematika dan Sains)}

Tersedia online di: http://e-journal.ikippgrimadiun.ac.id/index.php/JEMS

Volume 4, Nomor 2, September 2016, hal 76-84

matematika, investigasi (penyelidikan) mempunyai peran yang penting untuk melatih ketrampilan dan penalaran peserta didik melalui kajian bermakna (meaningful) yang terbuka terbatas (opened exploration) (Muhsetyo, 1999)". Selanjutnya, Orton (1992) menyatakan bahwa "dengan investigasi siswa akan belajar aktif dan memberi kesempatan pada siswa untuk berpikir sendiri”.

Height (dalam Krismanto, 2004) menyatakan "investigasi berkaitan dengan kegiatan mengobservasi secara rinci dan menilai secara sistematis". Menurut Eggen \& Kauchak (1996), ada beberapa kelebihan grup investigasi. Kelebihan grup investigasi yaitu (1) memfokuskan pada investigasi terhadap suatu topik atau konsep, (2) menyediakan kesempatan kepada siswa untuk membentuk atau mengajukan pertanyaan-pertanyaan yang bermakna, (3) efektif dalam membantu siswa untuk bekerja sama dalam kelompok dengan latar belakang yang berbeda, dan (4) menyediakan konteks sehingga siswa dapat belajar mengenai dirinya dan orang lain. Adapun kelemahan model grup investigasi jika dibandingkan dengan model belajar kooperatif yang lain adalah bahwa group investigasi merupakan model yang paling sulit dan kompleks untuk dilakukan (Ibrahim, 2000).

Berdasarkan uraian di atas, penerapan pembelajaran kooperatif investigatif untuk mempelajari materi barisan dan deret diasumsikan dapat digunakan dalam mengatasi permasalahan. Dengan pembelajaran kooperatif investigatif, siswa tidak sekadar menghafal rumus barisan dan deret, tetapi akan aktif terlibat secara fisik dan mental untuk menyelidiki pola/aturan yang menghasilkan rumus tersebut, siswa mendapat kebebasan untuk mengembangkan cara berpikirnya dan dapat membuat siswa mengetahui kemampuannya. Beberapa penelitian yang telah dilakukan dengan menerapkan pembelajaran grup investigasi memberikan dampak positif terhadap pembelajaran matematika. Salah satunya adalah penelitian yang dilakukan oleh Marinawatie (1999) menyatakan bahwa pembelajaran dengan model investigasi matematika ternyata dapat menghilangkan miskonsepsi siswa, bahkan meningkatkan pemahaman siswa tentang konsep pengukuran luas segitiga. Selanjutnya, Tamrin (2003) menyatakan bahwa penerapan pembelajaran kooperatif model grup investigasi dapat memahamkan siswa pada pembelajaran materi teorema Pythagoras dengan prestasi yang sangat baik dan menyatakan bahwa respon siswa terhadap model grup investigasi sangat positif, semua siswa menyatakan senang belajar dengan pembelajaran kooperatif model grup investigasi dan siswa lebih mudah mamahami materi pelajaran lingkaran.

Matematika dikenal sebagai suatu ilmu pengetahuan yang abstrak, yang dapat dipandang sebagai menstrukturkan pola, berpikir yang sistematis, kritis, logis, cermat, dan konsisten (Ansjar \& Sembiring, 2001). Matematika juga dapat diartikan sebagai aktivitas manusia. Matematika sebagai aktivitas manusia berarti manusia harus diberi kesempatan untuk menemukan kembali ide dan konsep matematika dengan bimbingan orang dewasa (Gravemeijer, 1994). Matematika terbentuk sebagai hasil pemikiran manusia yang berhubungan dengan ide, proses, dan penalaran.

Terkait dengan belajar matematika, Bruner (dalam Hudojo, 1998) menyatakan bahwa (1) belajar matematika adalah belajar tentang konsep-konsep dan struktur-struktur matematika yang terdapat dalam materi yang dipelajari serta hubungan antara konsepkonsep dan struktur-struktur matematika itu, (2) pembelajaran matematika tidak hanya pada melatih keterampilan dan menghafal fakta, tetapi pada pemahaman konsep, (3) pembelajaran matematika memerlukan keaktifan anak dalam proses belajar secara penuh.

Hiebert dan Carpenter (1992) berpendapat bahwa dalam belajar matematika, pemahaman merupakan aspek yang fundamental dalam belajar. Untuk dapat membuat siswa belajar matematika dengan pemahaman, guru hendaknya merencanakan dan melaksanakan pembelajaran yang melibatkan siswa aktif dalam belajar, baik secara mental, fisik, maupun sosial.Oleh karena itu, untuk menciptakan proses pembelajaran yang aktif yakni menciptakan kondisi belajar yang menantang dan melibatkan siswa untuk ikut berinteraksi aktif dalam pembelajaran secara individu dan 


\section{JEMS (Jurnal Edukasi Matematika dan Sains)}

Tersedia online di: http://e-journal.ikippgrimadiun.ac.id/index.php/JEMS

Volume 4, Nomor 2, September 2016, hal 76-84

kelompok, maka dalam penelitian ini diterapkan model pembelajaran kooperatif investigatif (pembelajaran dengan model Kooperatif tipe grup investigasi.

Pembelajaran kooperatif (cooperative learning) merupakan sistem pengajaran yang memberi kesempatan kepada anak didik untuk bekerja sama dengan sesama siswa dalam tugas-tugas yang terstruktur (Tim MKPBM, 2001).

Group investigasi adalah strategi belajar kooperatif yang menempatkan siswa ke dalam kelompok-kelompok secara heterogen dilihat dari perbedaan kemampuan, gender, etnis dan agama untuk melakukan investigasi terhadap suatu topik (Eggen \& Kauchak, 1996). Pelaksanaan pembelajaran model grup investigasi dapat menimbulkan dampak instruksional dan dampak pengiring bagi diri siswa. Joyce, $d k k$ (2009) menjelaskan bahwa dampak instruksional bagi siswa adalah (1) membentuk pandangan yang konstruksionis tentang pengetahuan, (2) mengembangkan penelitian yang berdisiplin, dan (3) melatih melakukan proses dan keteraturan kelompok secara efektif. Adapun dampak pengiringnya adalah (1) menghormati hak asasi manusia dan komitmen terhadap keanekaragaman, (2) kemerdekaan sebagi pelajar, (3) komitmen terhadap penelitian sosial, dan (4) kehangatan dan keterikatan antarmanusia.

Adapun dalam penelitian ini tahaptahap model group investigasi yang akan dilakukan adalah model yang diterapkan oleh Thellen, yaitu (1) siswa dihadapkan dengan siatuasi problematis, (2) siswa melakukan eksplorasi sebagai respon terhadap situasi problematis, (3) siswa merumuskan tugastugas belajar atau learning task dan mengorganisasikan untuk belajar, (4) siswa melakukan kegiatan belajar perorangan atau kelompok, (5) siswa menganalisis kemajuan dan proses yang dilakukan dalam belajar kelompok, dan (6) melakukan proses pengulangan atau recycle activity.

\section{METODE PENELITIAN}

Jenis penelitian ini merupakan Penelitian Tindakan Kelas (PTK). Penelitian tindakan kelas (PTK) adalah suatu bentuk kegiatan refleksi diri yang dilakukan oleh para pelaku pendidikan dalam suatu situasi kependidikan untuk memperbaiki rasionalitas dan keadilan tentang: praktik-praktik kependidikan, pemahaman tentang praktikpraktik tersebut, dan situasi di mana praktikpraktik tersebut dilaksanakan (Kunandar, 2008)

Adapun prosedur PTK yang akan diterapkan dalam penelitian ini akan mengacu pada model Kemmis dan Mc Taggart. Langkah-langkah tersebut berupa siklus yang terdiri dari empat tahap, yaitu: perencanaan (plan), pelaksanaan tindakan (action), pengamatan (observation), dan refleksi (reflection).

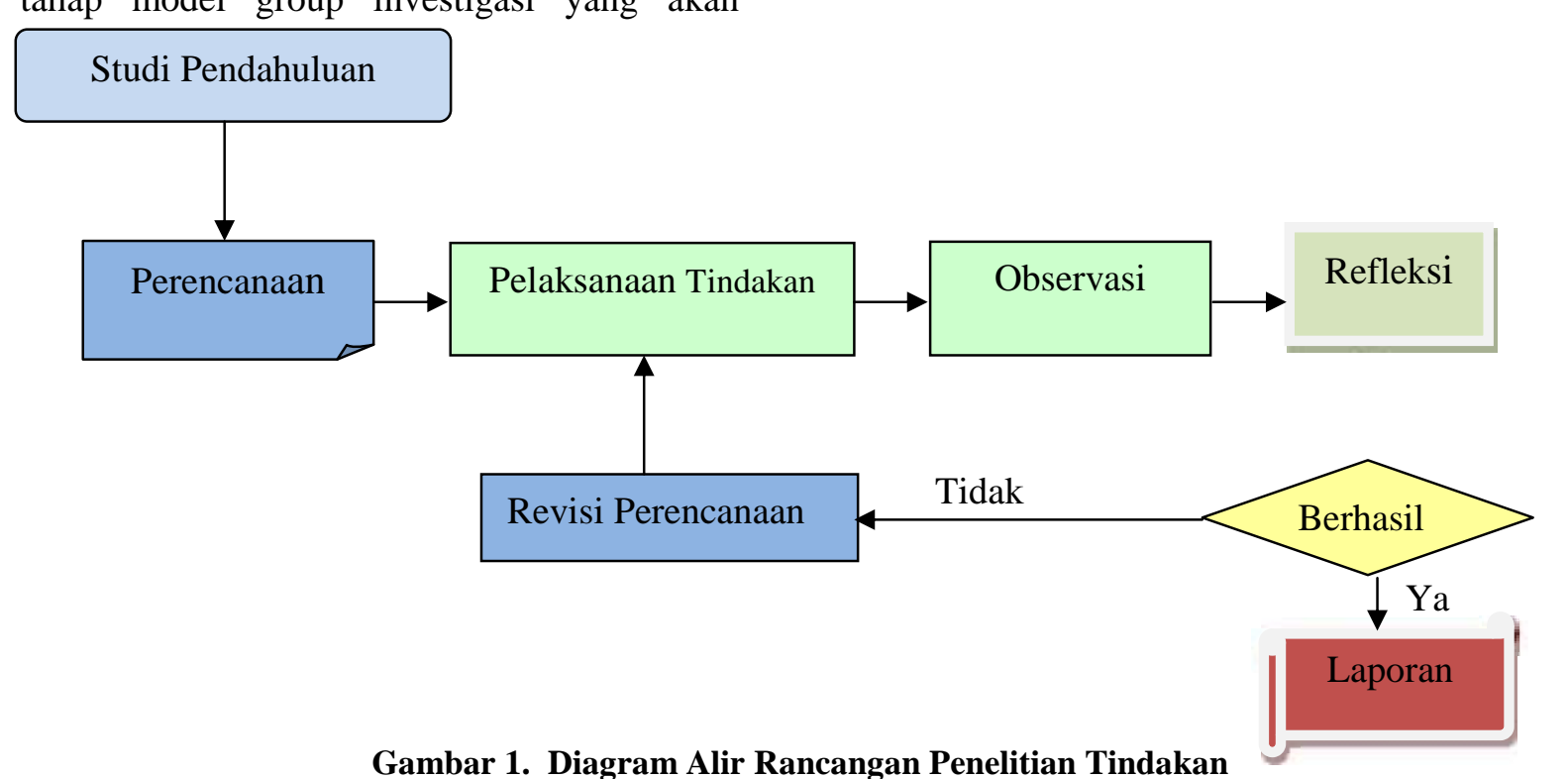




\section{JEMS (Jurnal Edukasi Matematika dan Sains)}

Tersedia online di: http://e-journal.ikippgrimadiun.ac.id/index.php/JEMS

Volume 4, Nomor 2, September 2016, hal 76-84

Instrumen penelitian yang digunakan adalah (a) lembar kerja siswa (LKS) (b) lembar tes (c) lembar observasi aktivitas siswa (d) lembar observasi aktivitas guru (e) format wawancara. Prosedur pengumpulan data yang digunakan dalam penelitian ini adalah observasi aktivitas guru dan aktivitas siswa, tes pada akhir siklus, wawancara dan membuat catatan lapangan, serta dokumentasi. Teknik analisis data yang akan digunakan adalah model alir (flow model) yang dikemukakan
Miles dan Huberman (1992) yang meliputi kegiatan (1) mereduksi data, (2) menyajikan data, dan (3) menarik kesimpulan serta verifikasi.

\section{HASIL PENELITIAN}

Hasil penelitian ini dapat diuraikan sebagai berikut.

Hasil observasi aktivitas guru dan siswa

Hasil observasi yang diberikan oleh obsever dapat dilihat dalam Tabel 2 berikut.

Tabel 2 Hasil Observasi oleh Observer

\begin{tabular}{|c|c|c|c|c|c|c|c|}
\hline \multirow[t]{2}{*}{ Pertemuan } & & \multicolumn{3}{|c|}{ Aktivitas Siswa } & \multicolumn{3}{|c|}{ Aktivitas Guru } \\
\hline & & OI & OII & OIII & OI & OII & OIII \\
\hline \multirow{5}{*}{$\begin{array}{l}\text { Pertemuan } \\
\text { pertama }\end{array}$} & Skor perolehan & 37 & 34 & 36 & 51 & 48 & 42 \\
\hline & Jumlah & \multicolumn{3}{|c|}{107} & \multicolumn{3}{|c|}{141} \\
\hline & Skor rata-rata & \multicolumn{3}{|c|}{35,67} & \multicolumn{3}{|c|}{47} \\
\hline & Persentase & \multicolumn{3}{|c|}{$79,26 \%$} & \multicolumn{3}{|c|}{$78,33 \%$} \\
\hline & Kriteria & \multicolumn{3}{|c|}{ Cukup Aktif } & \multicolumn{3}{|c|}{ Cukup Baik } \\
\hline \multirow{5}{*}{$\begin{array}{l}\text { Pertemuan } \\
\text { kedua }\end{array}$} & Skor perolehan & 41 & 39 & 38 & 48 & 51 & 44 \\
\hline & Jumlah & \multicolumn{3}{|c|}{118} & \multicolumn{3}{|c|}{143} \\
\hline & Skor rata-rata & \multicolumn{3}{|c|}{39,33} & \multicolumn{3}{|c|}{47,67} \\
\hline & Persentase & \multicolumn{3}{|c|}{$87,41 \%$} & \multicolumn{3}{|c|}{$79,45 \%$} \\
\hline & Kriteria & \multicolumn{3}{|c|}{ Aktif } & \multicolumn{3}{|c|}{ Cukup Baik } \\
\hline \multirow{5}{*}{$\begin{array}{l}\text { Pertemuan } \\
\text { ketiga }\end{array}$} & Skor perolehan & 44 & 42 & 43 & 52 & 49 & 49 \\
\hline & Jumlah & \multicolumn{3}{|c|}{129} & \multicolumn{3}{|c|}{150} \\
\hline & Skor rata-rata & \multicolumn{3}{|c|}{43} & \multicolumn{3}{|c|}{50} \\
\hline & Persentase & \multicolumn{3}{|c|}{$95,56 \%$} & \multicolumn{3}{|c|}{$83,33 \%$} \\
\hline & Kriteria & \multicolumn{3}{|c|}{ Sangat Aktif } & \multicolumn{3}{|c|}{ Baik } \\
\hline \multirow{5}{*}{$\begin{array}{l}\text { Pertemuan } \\
\text { keempat }\end{array}$} & Skor perolehan & 44 & 44 & 44 & 59 & 59 & 57 \\
\hline & Jumlah & \multicolumn{3}{|c|}{132} & \multicolumn{3}{|c|}{175} \\
\hline & Rata-rata & \multicolumn{3}{|c|}{44} & & 58 & \\
\hline & Persentase & & 97 & & & 97,2 & \\
\hline & Kriteria & & Sanga & & & Sanga & \\
\hline
\end{tabular}

Kriteria keberhasilan yang ditetapkan untuk aktivitas guru minimal berada pada kategori cukup baik. Dengan demikian, proses pembelajaran pada siklus ini telah terlaksana dengan baik. Dari hasil ini dapat disimpulkan bahwa kriteria yang ditetapkan peneliti telah tercapai. kriteria keberhasilan yang diperoleh untuk aktivitas siswa minimal berada pada kategori cukup aktif. Dari hasil ini dapat disimpulkan bahwa kriteria yang ditetapkan peneliti telah tercapai.

Hasil Tes evaluasi

Setelah empat kali pertemuan, untuk mengetahui tingkat pemahaman siswa terhadap materi barisan dan deret, peneliti melakukan tes. Tes dilaksanakan pada pertemuan ke lima yang dilaksanakan pada hari Kamis tanggal 17 Maret 2011. Pada saat tes dilaksanakan, semua siswa hadir, yaitu sebanyak 33 siswa.

Tabel 3. Hasil evaluasi

\begin{tabular}{clc}
\hline No & \multicolumn{1}{c}{ Keterangan } & Jumlah \\
\hline 1 & Jumlah siswa & 33 \\
2 & Jumlah siswa yang ikut tes & 33 \\
3 & Nilai tertinggi & 100 \\
4 & Nilai terendah & 77 \\
5 & Nilai rata-rata & 84,39 \\
6 & Jumlah siswa yang tuntas & 33 \\
7 & Jumlah siswa yang tidak tuntas & 3 \\
8 & Persentase ketuntasan klasikal & $100 \%$ \\
\hline
\end{tabular}




\section{JEMS (Jurnal Edukasi Matematika dan Sains) \\ Tersedia online di: http://e-journal.ikippgrimadiun.ac.id/index.php/JEMS \\ Volume 4, Nomor 2, September 2016, hal 76-84}

Selanjutnya, berdasarkan hasil tes akhir, diperoleh data hasil belajar siswa dengan nilai terendah 77 dan nilai tertinggi adalah 100 . Dengan ketuntasan klasikal 100\%. Dengan demikian hasil ini menunjukkan bahwa kriteria yang peneliti tetapkan telah tercapai, yaitu minimal $85 \%$ siswa mendapat nilai lebih dari atau sama dengan 75 . Hal ini berarti bahwa kriteria keberhasilan untuk hasil belajar siswa yang telah ditetapkan telah tercapai.

\section{Hasil Wawancara}

Wawancara dilakukan oleh peneliti setelah siswa mengikuti tes evaluasi. Penentuan objek wawancara didasarkan pada nilai tes evaluasi. Masing-masing objek dipilih berdasar tingkat kemampuan, yaitu siswa yang berkemampuan rendah, sedang, dan tinggi. Hasil wawancara kemudian dibandingkan dengan hasil tes akhir. Objek wawancara terpilih terdiri dari dua orang siswa laki-laki dan seorang siswa perempuan. Berdasar hasil wawancara dengan ketiga objek wawancara dapat disimpulkan bahwa siswa dapat menguasai konsep barisan dan deret dengan baik. Adapu kesalahankesalahan yang terjadi karena faktor keteledoran dari siswa saja. Setelah dikonfirmasi kesalahan tersebut, ternyata siswa tersebut dapat menyelesaikan soal dengan baik. Selain itu, berdasarkan jawaban siswa ketika diwawancarai tentang proses pembelajaran, dapat diketahui bahwa pembelajaran kooperatif investigatif dapat membuat siswa senang dalam mempelajari barisan dan deret.

Berdasarkan hasil analisis ini, semua aspek kriteria keberhasilan pembelajaran yang telah ditetapkan telah tercapai. Dengan demikian disimpulkan bahwa penelitian telah berhasil dan tindakan penelitian tidak perlu dilanjutkan.

\section{PEMBAHASAN}

Berdasarkan pemaparan $\begin{array}{r}\text { hasil } \\ \text { penelitian, diperoleh informasi bahwa }\end{array}$
pelaksaan penelitian dilaksanakan dalam satu
siklus. Hal ini terjadi karena berdasar hasil
refleksi bahwa semua indikator keberhasilan
penelitian sudah tercapai sehingga penelitian
tidak perlu dilanjutkan ke siklus selanjutnya
dan selanjutnya disusun laporan. Hasil
penelitian ini didukung dengan proses
pembelajaran yang baik. Proses keterlaksanaan

pembelajaran berada pada minimal berada kategori baik setiap pertemuan, artinya proses pembelajaran berjalan dengan cukup baik dan lancar. Aktivitas siswa dalam belajar minimal berada pada kategori sangat aktif. Artinya siswa cukup antusias belajar dengan design pembelajaran kooperatif.

Pembelajaran kooperatif investigatif yang didesain dalam penelitian ini merupakan sistem pembelajaran yang memberi kesempatan kepada siswa agar dapat bekerja sama dengan siswa lain untuk melakukan investigasi terhadap suatu topik tertentu. Dalam pelaksanaan pembelajaran kooperatif investigatif ini, siswa belajar dalam kelompokkelompok kecil yang terdiri dari 5-6 siswa untuk menyelesaikan permasalahan dan untuk mencapai tujuan pembelajaran.

Belajar secara berkelompok memberikan banyak keuntungan bagi siswa. Dalam belajar kelompok, siswa saling berdiskusi dan bertukar pikiran dalam menyelesaikan masalah yang diberikan. Para siswa saling memberikan bantuan dan masukan dalam meningkatkan pemahamannya tentang suatu konsep yang dipelajari. Siswa yang kurang mampu dan agak lambat dalam memahami materi dapat bertanya kepada teman-temannya yang lebih mampu mengenai hal-hal yang belum dipahami. Sebaliknya, siswa yang memiliki kemampuan yang lebih dan cepat dalam memahami materi dapat semakin menambah pemahamannya melalui proses memberikan penjelasan kepada temantemannya yang kurang mampu dan agak lambat dalam memahami suatu konsep yang belum dipahami. Hal ini sesuai dengan pendapat Eggen \& Kauchak (1996) yang menyatakan bahwa "dalam kerja kelompok peserta didik akan saling belajar melalui proses saling menerima dan memberi yang terjadi dalam kelompok".

Dalam pelaksanaannya, pembelajaran kooperatif investigatif pada materi barisan dan deret dilakukan dengan menggunakan lembar kerja siswa (LKS). LKS merupakan suatu bentuk bantuan bagi siswa dalam belajar. LKS berisi permasalahan yang harus dikerjakan siswa beserta langkah-langkah penyelesaiannya. Langkah-langkah yang ditentukan dalam LKS merupakan suatu 


\section{JEMS (Jurnal Edukasi Matematika dan Sains)}

Tersedia online di: http://e-journal.ikippgrimadiun.ac.id/index.php/JEMS

Volume 4, Nomor 2, September 2016, hal 76-84

bentuk bantuan bagi siswa. Meskipun di dalam LKS sudah termuat langkah-langkah penyelesaian, LKS tidak menuntun siswa secara mutlak. LKS hanya memuat pertanyaan dan langkah-langkah penyelesaiannya secara garis besarnya saja. Selebihnya, siswa diberi kesempatan sebebas-bebasnya untuk mengungkapkan ide dan kreativitasnya sendiri dalam menyelesaikan suatu masalah yang diberikan sehingga siswa dapat mengkonstruksi pemahamannya sendiri. Selain itu, dengan bantuan LKS siswa dapat belajar dengan berdiskusi bersama teman kelompoknya sehingga siswa dapat melakukan penemuan-penemuan.

Pelaksanaan pembelajaran kooperatif investigatif dilakukan dalam tiga tahap, yaitu tahap pendahuluan, tahap inti, dan tahap penutup. Pada tahap pendahuluan, siswa dipersiapkan untuk belajar. Kegiatan ini dilakukan dengan cara melakukan persiapan fisik maupun mental. Persiapan fisik meliputi pengaturan posisi duduk dan pengaturan tempat masing-masing kelompok. Persiapan mental meliputi kegiatan menyampaikan salam, memotivasi siswa untuk aktif berdiskusi, melakukan dialog-dialog, dan menyampaikan materi prasyarat. langkah-langkah pembelajaran kooperatif investigatif pada materi barisan dan deret mulai dilakukan. Langkah pertama, siswa dihadapkan dengan situasi problematik. Dalam hal ini, situasi problematik diberikan melalui LKS yang berisi masalah yang harus dikerjakan secara berkelompok. Masalah yang diberikan dalam LKS tersebut bersifat menantang sehingga memungkinkan siswa untuk berpikir dan melakukan diskusi di dalam kelompoknya. Masalah yang diberikan tersebut juga disesuaikan dengan "dunia" siswa. Pada pertemuan pertama, siswa cukup kesulitan menyelesaikan LKS. Akibatnya waktu belajar siswa menjadi molor. Kondisi ini menggangu proses pembelajaran. Oleh karena itu, sebelum pertemuan kedua dan seterusnya dilaksanakan, peneliti memberikan LKS terlebih dahulu kepada siswa agar dapat menyelesaikannya di rumah dan mencari literatur-literatur yang memadai. Pembelajaran pada pertemuan kedua dan seterusnya berjalan lebih baik.

Langkah kedua, siswa melakukan eksplorasi terhadap masalah yang diberikan.
Eksplorasi ini merupakan respon siswa terhadap situasi problematik yang diberikan. Dalam hal ini, siswa diberi kesempatan untuk membaca dan memahami permasalahan yang diberikan. Dengan adanya pemahaman yang baik terhadap permasalahan yang diberikan, siswa diharapkan dapat menemukan solusi atau pemecahan yang baik pula terhadap permasalahan tersebut. Kegiatan eksplorasi ini hanya bentuk pengulangan dari pelaksaan proses pembelajaran yang dilakukan dirumah dalam menyelesaikan LKS.

Langkah ketiga, siswa merumuskan tugas-tugas belajar atau learning task dan mengorganisasikan tugas tersebut serta diri mereka sendiri untuk belajar. Pada dasarnya, kegiatan perumusan tugas-tugas belajar atau learning task dan pengorganisasian untuk belajar tidak terpisah dari kegiatan eksplorasi. Dalam hal ini, siswa membagi tugas untuk menyelesaikan permasalahan, siswa melakukan diskusi bersama teman kelompoknya tentang fokus investigasi, cara melakukan investigasi, dan tujuan melakukan investigasi. Pembagian tugasdilaksanakan sesuai dengan hasil belajar siswa di rumah. Selanjutnya, kegiatan pada langkah ini dapat disebut juga dengan kegiatan investigasi. Dalam melakukan investigasi siswa berusaha menyelesaikan masalah yang diberikan sesuai tugas yang diberikan. Jika tugas sudah dikerjakan dirumah maka siswa memahaminya secara lebih mendalam. Dalam kegiatan menyelesaikan masalah ini diharapkan siswa dapat memperoleh dan menyusun pemahaman mereka tentang materi yang dipelajari secara aktif. Hal ini sejalan dengan para ahli konstruktivisme yang menyatakan bahwa ketika siswa mencoba menyelesaikan tugastugas di dalam kelas, maka pengetahuan matematika dikonstruksi secara aktif (Cobb, 1992).

Langkah keempat, siswa melakukan kegiatan belajar kelompok. Dalam melakukan belajar kelompok ini siswa berdiskusi bersama teman kelompok untuk membuat rangkuman tentang hal-hal yang penting untuk dilaporkan dan kemudian mendiskusikannya. Setelah membuat rangkuman, siswa sering bertanya tentang hasil rangkuman mereka. Dalam hal ini, peneliti berusaha menguatkan pemahaman siswa dengan memberikan pertanyaan- 


\section{JEMS (Jurnal Edukasi Matematika dan Sains)}

Tersedia online di: http://e-journal.ikippgrimadiun.ac.id/index.php/JEMS

Volume 4, Nomor 2, September 2016, hal 76-84

pertanyaan. Pemberian pertanyaan dilakukan agar siswa benar-banar dapat berpikir lebih luas dalam memahami materi sebelum mereka melaporkan hasil pekerjaan mereka di depan kelas.

Langkah kelima, siswa menganalisis kemajuan dan proses. Pada dasarnya, langkah kelima dan langkah keempat, yaitu siswa melakukan kegiatan belajar kelompok, dilaksanakan secara bersamaan, yaitu pada saat siswa menyajikan laporan. Dalam menganalisis kemajuan dan proses ini, terjadi diskusi kelas antar kelompok sebagai reaksi kelompok pembanding terhadap kelompok pelapor. Dalam diskusi ini, kelompok saling bertanya jawab dan menyampaikan sanggahan. Diskusi antar kelompok terjadi karena adanya kesalahan yang disampaikan pelapor dan atau karena adanya kekurangan-kekurangan. Kesalahan-kesalahan dari laporan tersebut dikoreksi oleh kelompok pembanding.

Langkah keenam, siswa melakukan proses pengulangan atau recycle activity. Pada langkah keenam ini, dilakukan diskusi melalui tanya jawab, baik secara lisan maupun tertulis. Kegiatan ini dilakukan untuk mengevaluasi dan memastikan semua siswa telah memiliki pemahaman terhadap materi yang baru saja dipelajari. Tanya jawab secara tertulis dilakukan dengan memberikan beberapa soal untuk dikerjakan oleh siswa secara individu sebagai latihan. Sebagai penutup atas bimbingan dan arahan kepada siswa, peneliti membantu siswa menyamakan pendapat dan pemahaman tentang materi yang dipelajari dan meminta siswa membuat rangkuman dari hasil diskusinya sebagai simpulan akhir pembelajaran.

Berdasarkan pemaparan tersebut, ada tiga hal yang diperoleh siswa dengan pembelajaran kooperatif investigatif. Pertama, grup investigasi membantu siswa untuk menginvestigasi terhadap suatu topik secara sistematik dan analitik. Hal ini berakibat pada pengembangan keterampilan penemuan dan membantu untuk mencapai tujuan. Kedua, pemahaman yang mendalam terhadap topik yang diberikan. Ketiga, dalam grup investigasi, siswa belajar cara bekerja sebagai kooperatif dalam memecahkan masalah. Belajar untuk bekerja sama merupakan keterampilan hidup (life skill) yang berharga dalam hidup bermasyarakat. Jadi, guru dalam menerapkan model grup investigasi dapat mencapai tiga hal, yaitu belajar dengan penemuan, belajar isi, dan belajar untuk bekerja secara kooperatif (Maimunah, 2005:22).

\section{KESIMPULAN}

Berdasar pada paparan data dan pembahasan dapat disimpulkan beberapa hal berikut.

Pembelajaran kooperatif investigatif dapat meningkatkan pemahaman siswa materi barisan dan deret. Langkah-langkah pembelajaran kooperatif investigatif yang digunakan dalam memahamkan siswa materi barisan dan deret terdiri dari beberapa langkah, yaitu (a) kegiatan pendahuluan, (b) memberikan masalah melalui LKS untuk kerja kelompok, (c) siswa secara berkelompok melakukan eksplorasi terhadap masalah, (d) siswa secara berkelompok melakukan analisis secara mendalam, (e) siswa melakukan pelaporan dan melakukan diskusi kelas, (f) melakukan aktivitas pengulangan, dan (g) penutup (memberikan LKS untuk dikerjakan scara individu di rumah dan akan dibahas pada pertemuan berikutnya). Hal ini didukung dengan proses pelaksanaan pembelajaran yang berjalan lancar, siswa aktif, dan hasil tes evaluasi yang memenuhi kriteria keberhasilan penelitian serta hasil wawancara yang menunjukkan bahwa siswa mempunyai respon yang sangat positif terhadap pembelajaran kooperatif. Siswa menyatakan senang belajar dengan pembelajaran kooperatif investigatif dengan berbagai macam alasan tertentu.

\section{DAFTAR PUSTAKA}

Ansyar \& Sembiring,R.K. (2001). Hakikat Pembelajaran MIPA dan Kiat Pembelajaran Matematika di Perguruan Tinggi. Jakarta: PAU-PPAI Universitas Terbuka.

As'ary, A. (2002). Membantu Siswa Membuat Konjektur Matematis Sebagai Bagian dari Upaya Pembelajaran Proses Matematika Bernalar. Jurnal matematika atau pembelajarannya ; prosiding konferensi nasional matematika, edisi khusus. XI.(1):333334. 


\section{JEMS (Jurnal Edukasi Matematika dan Sains)}

Tersedia online di: http://e-journal.ikippgrimadiun.ac.id/index.php/JEMS

Volume 4, Nomor 2, September 2016, hal 76-84

Cobb,P., Yackel, E., \& Wood, T. (1992). A constuctivist alternative to the representational views of mind in mathematics education. Journal for research in mathematics education, 23(1), 2-33.

Eggen, P.D. \& Kauchak, P.P. (1996). Strategies for Teachers: Teaching Conten and Thinking Skill. Boston: Allyn \& Bacon

Gravemeijer, F. P. (1994). Developing Realistics Mathematics Education. Utrecht : $\quad$ Freudenthal Institute.

Hudojo. (1998). Pembelajaran matematika menurut pandangan konstruktivis. Makalah disajikan pada seminar nasional "upaya meningkatkan peran pendidikan matematika dalam era Globalisasi” PPS IKIP Malang: 4 april

Ibrahim, M., F. Rachmadiarti, M. Nur, dan Ismono. (2000). Pembelajaran Kooperatif. Surabaya:Unesa University Press.

Joyce, B., Weil, M.,Calhoun, E. (2009). Models of Teaching. (Terjemahan). Yogyakarta: Pustaka Pelajar.

Krismanto, A. (2003). Beberapa Teknik, Model, dan Strategi Pembelajaran Matematika. Yogyakarta: Pusat Pengembangan Penataran Guru Matematika (PPPG).

Kunandar. (2008). Penelitian Tindakan Kelas. Jakarta: Rajawali Pers.

Maimunah. (2005). Pembelajaran Volume Bola Dengan Belajar Kooperatif Model Group Investigasi Pada Siswa Kelas $X \quad$ Sma Laboratorium Universitas Negeri Malang. Malang: PPS UM. Tesis tidak diterbitkan.

Marinawatie, A. (1999). Penerapan Strategi Investigasi Matematika untuk
Meningkatkan Pemahaman Siswa Tentang Konsep Pengukuran Luas Segitiga. Malang: PPS UM. Tesis tidak diterbitkan

Milles,B.Mattew. \& Huberman, Michael.A. (1992). Analisis Data Kualitatif (Terjemahan Tjejep Rohendi Rohidi). Jakarta: UI Press

Muhsetyo, G. (1999). Strategi Investigasi Dalam Pembelajaran Persamaan Linier Dua Variabel. Jurnal jurusan pendidikan matematika FMIPA IKIP Malang: 73-82.Orthon, A. 1992. Learning Mathematic: Issues, Theory, and Practice. Great Britain: Redwook Books.

Pandjo, K. (2003). Belajar bermakna melalui pembuatan konjektur mathematic untuk pemahaman siswa menentukan rumus suku ke-n dan barisan erithmatika di SLTPN 2 Luwuk. Malang: PPS UM. Tesis tidak diterbitkan.

Tamrin. (2003). Penerapan Pendekatan Kooperatif Model Grup Investigasi untuk Meningkatkan Prestasi Siswa pada Pembelajaran Materi Teorema Pythagoras. Tesis tidak diterbitkan. Malang: PPs UM.

Tim MKPBM. (2001). Strategi Pembelajaran Matematika Kontemporer. Bandung: JICA Universitas Pendidikan Indonesia. 